\title{
CONFLUENT PERIPHERAL MULTIPLE MONONEUROPATHY ASSOCIATED TO ACUTE HEPATITIS B: A CASE REPORT
}

\author{
Marcello CANIELlo(1), Patrícia BAXTER(2), Angelina Maria Martins LINO(3), Leandro Gregorut LIMA(4) \& Walkyria Pereira PINTO(5)
}

\begin{abstract}
SUMMARY
A thirty three year-old, male patient was admitted at the Hospital of the São Paulo University School of Medicine, at the city of São Paulo, Brazil, with complaint of pains, tingling and decreased sensibility in the right hand for the last four months. This had progressed to the left hand, left foot and right foot, in addition to a difficulty of flexing and stretching in the left foot. Tests were positive for $\mathrm{HBeAg}$, IgM anti-HBc and $\mathrm{HBsAg}$, thus characterizing the condition of acute hepatitis B. The ALT serum level was 15 times above the upper normal limit. Blood glucose, cerebral spinal fluid, antinuclear antibodies (ANA) and anti-HIV and anti-HCV serum tests were either normal or negative. Electroneuromyography disclosed severe peripheral neuropathy with an axon prevalence and signs of denervation; nerve biopsy disclosed intense vasculitis. The diagnosis of multiple confluent mononeuropathy associated to acute hepatitis B was done. This association is not often reported in international literature and its probable cause is the direct action of the hepatitis B virus on the nerves or a vasculitis of the vasa nervorum brought about by deposits of immune complexes.
\end{abstract}

KEYWORDS: Peripheral neuropathy; Hepatitis B; Denervation.

\section{INTRODUCTION}

Peripheral mononeuropathy is a rare complication of acute viral hepatitis, with an inferred prevalence of $0.04 \%$. It causes however, a significant injury for the patient. The clinical picture has a mean duration from three months to two years but, as a rule, has a benign evolution and complete remission of the neurological features ${ }^{4,5,6}$.

Here we report a case of peripheral multiple mononeuropathy associated to acute hepatitis B that, as already reported, followed a slow course. This is a rare complication and few cases associated with positive serological tests for acute hepatitis B were recorded in the international literature.

\section{CASE REPORT}

Male patient, 33 year-old, Brazilian, was admitted with complaint of pains, tingling and decreased sensibility on the right hand for the last four months, which had progressed sequentially to the left hand, left foot and right foot in a time period of three months after onset of the condition, without further complaints. Liver enzymes were performed three months before and showed an increase of 15 times of the ALT, above the upper normal limit. At that time he was anicteric.

He works as hairdresser and the main risk factor for his HBV infection was homossexual relationships. He denied alcoholism.
On admission serology for hepatitis B was reagent for HBsAg, IgM anti-HBc, HBeAg and not for anti-HBs and anti-HBe. Anti-HCV, HTLV and HIV serological reactions, as well as test for HIV by PCR were negatives. Erythrocyte sedimentation rate, glucose, antinuclear antibodies (ANA's) and bilirrubins are normal. Biochemical and immunological trials for liquor did not present alterations. The ALT was seven times above the upper normal limit.

The patient showed worsening of the pain, mainly in the plantar region of the left food hindering gait and disabling him for work. Upon hospitalization he reported tingling and decrease of sensibility to heat and pain on the palm side of the first, second and third fingers of the right hand. Tingling in the fifth finger of the left hand, pain and tingling on the lateral side of the right foot, incapacity to perform flexing and stretching of the left foot, severe pain and "shocks" in the plantar region of the left foot.

The physical examination disclosed no jaundice and no fever with the gait hindered by the dysesthesia of the left foot plantar region, decreased Achilles tendon reflex to the right and null to the left, bilateral decrease of the patelar reflex, diminished sensibility to pain in the first, second and third fingers of the right hand and on the instep of both feet and increased on the plantar region of the left foot and incapacity to perform flexing and stretching of the left foot.

(1) Student of the School of Medicine of the São Paulo University (FMUSP), SP, Brazil.

(2) Resident physician of the Clinical Division of Infectious and Parasitic Diseases of the Hospital das Clínicas of the FMUSP, SP, Brazil.

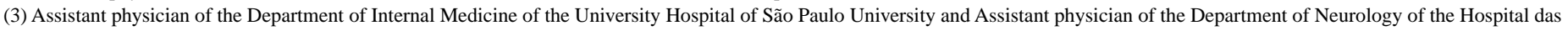
Clínicas of the FMUSP, SP, Brazil.

(4) Student of the School of Medicine of the São Paulo University (FMUSP), SP, Brazil.

(5) Assistant Professor PhD of the Department of Infectious and Parasitic Diseases of the Hospital das Clínicas of the FMUSP, SP, Brazil.

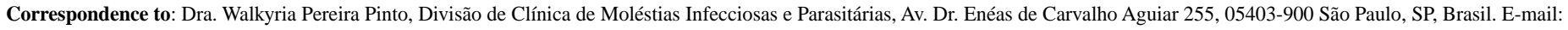
walkpp@usp.br 
Electroneuromyography showed severe sensitive-motor peripheral neuropathy, with an axon prevalence, with signs of denervation, causing a mild-distal impairment of the lower limbs. After sural nerve biopsy at the left, it was observed that the different epineurium and endoneurium blood vessels presented with thickened walls, while congo red test staining did not exhibit deposit of amyloid substance. The vascular wall of the epineural vessels were damaged, with intramural and perivascular inflammatory infiltration. The semi-thin slabs exhibited severe reduction of the number of myelin fibers (700 fibers $/ \mathrm{mm}^{2}$ of the endoneural area), various totally demyielinated axons were viewed and numberless digestion chambers (Fig. 1).

We conclude that this was a case of peripheral multiple mononeuropathy associated with acute hepatitis B. After receiving Amitriptyline, Oxycarbamazepine, Chloropromazine and Tramadol on admission the patient's aching features improved. Lamivudine was started (150 mg per day) five months after the onset of the symptoms. Total recovery of the movements and of the sensibility and normal levels of transaminases were obtained seven and eleven months after the onset of symptoms, respectively.

At the eleventh month of follow up the serologic tests still disclosed seropositivity for $\mathrm{HBsAg}$ and $\mathrm{HBeAg}$ with anti-HBs and anti-HBe negative results.

\section{DISCUSSION}

The temporal relationship between the hepatic lesion and the nerve injury and the absence of another apparent cause for the neuropathy besides that of acute viral hepatitis were considered to be evidences of the association between the neuropathy and the HBV infection in this patient.

We can't attribute the improvement straightly to Lamivudine, because he was already having improvement of the symptoms before receiving this drug.

Peripheral neuropathies are rare complications in patients with acute hepatitis $\mathrm{B}^{1,3,5}$. The Guillain-Barré syndrome is apparently the more common among the peripheral neuropathies associated to this viral disease ${ }^{2,5}$. In acute hepatitis B other polyneuropathies have also been described $^{1,2,5}$, however more rare than the Guillain-Barré syndrome. Peripheral multiple mononeuropathies are even more rare than the previously mentioned ones ${ }^{5}$.

Pathogenesis of the mononeuropathy as a complication of acute hepatitis B has not yet been fully elucidated. Studies in this area suggest that the lesion results from action of the virus itself on the nervous fibers or perhaps from deposits of immune complexes on the vasa nervorum of the nerves leading to vasculitis and consequent ischemia of the nervous fibers $^{3,5,7}$.

In presence of an acute anicteric hepatitis $B$, peripheral mononeuropathies and polineuropathies may concurrently take place ${ }^{2,5}$. Therefore, for patients with peripheral neuropathy of unknown cause such as the one presented in this report, the importance of detailed evaluation of the epidemiological history, of the liver function and of serological tests for hepatitis B virus infection must be highlighted.

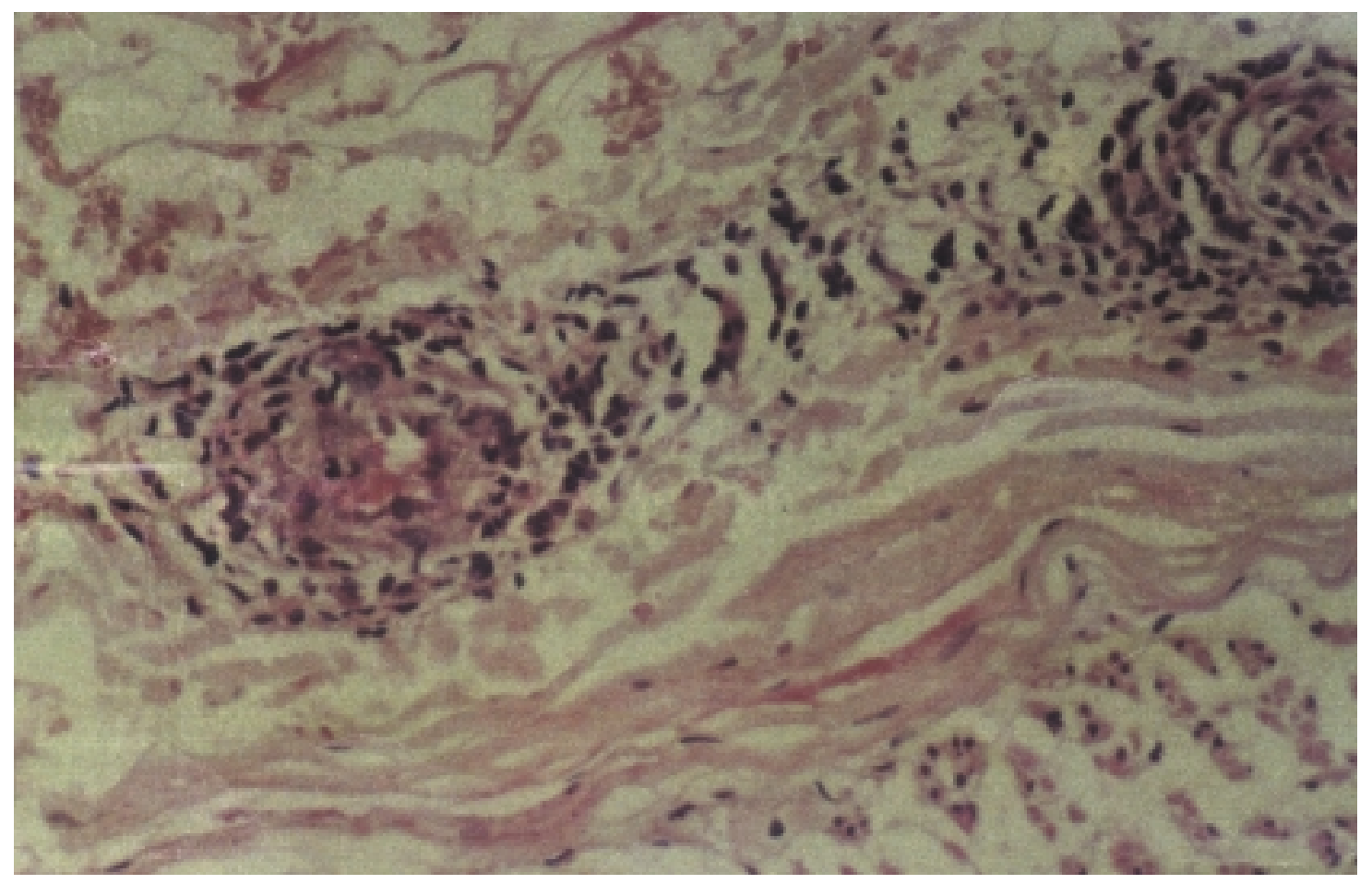

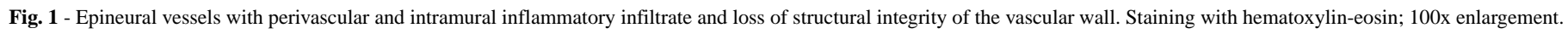




\section{RESUMO}

\section{Mononeuropatia múltipla periférica confluente associada a hepatite $B$ aguda: relato de caso}

Um paciente de 33 anos, do sexo masculino, foi internado no Hospital das Clínicas da Faculdade de Medicina da Universidade de São Paulo, SP, Brasil, queixando-se de dores, formigamento e diminuição da sensibilidade em mão direita há quatro meses, que progrediram para mão esquerda e ambos os pés, com surgimento de dificuldade de flexão e extensão do pé esquerdo.

As pesquisas de anti-HBc IgM, HBeAg e HBsAg foram positivas, caracterizando quadro de hepatite $\mathrm{B}$ aguda, com ALT atingindo valores quinze vezes acima da normalidade. Os exames de glicemia, FAN, líquor, sorologias anti-HIV e anti-HCV foram normais ou negativos.

A eletroneuromiografia mostrou intensa neuropatia periférica de predomínio axonal, com sinais de desnervação; a biópsia de nervo demonstrou intensa vasculite. Foi feito o diagnóstico de mononeuropatia múltipla confluente associada a hepatite B aguda.

Esta associação é pouco referida na literatura internacional, e tem como causa provável uma ação direta do vírus da hepatite B sobre os nervos ou uma vasculite da vasa nervorum causada pela deposição de imunocomplexos.

\section{REFERENCES}

1. ASBURY, A.K. - Hepatic neuropathy. In: DYCK, P.J.; THOMAS, P.K.; LAMBERT, E.H. \& BUNGE, R. - Peripheral neuropathy. 2.ed. Philadelphia, W.B. Saunders, 1984. p. $1826-1828$.

2. BERGER, J.R.; AYYAR, R. \& SHEREMATA, W.A. - Guillain-Barre syndrome complicating acute hepatitis B. A case with detailed electrophysiological and immunological studies. Arch. Neurol., 38: 366-368, 1981.

3. FARIVAR, M.; WANDS, J.R.; BENSON, G.D.; DIENSTAG, J.L. \& ISSELBACHER, K.J. - Cryoprotein complexes and peripheral neuropathy in a patient with chronic active hepatitis. Gastroenterology, 71: 490-493, 1976.

4. FLATAU, E.; RESNITZKY, P. \& KOHN, D. - Hepatitis B antigen associated with cryoglobulinemia, peripheral neuropathy, and myopathy. J. Amer. med. Ass., 243: 1526,1980

5. PELLETIER, G.; ELGHOZI, D.; TREPO, C.; LAVERDANT, C. \& BENHAMOU, J.P. Mononeuritis in acute viral hepatitis. Digestion., 32: 53-56, 1985.

6. SAIZ-HERVAS, E.; JIMENEZ-JIMENEZ, F.J.; VAQUERO, A. et al. - Peripheral neuropathy, first manifestation of hepatitis B virus infection. Presse med., 24: 548 , 1995.

7. TSUKADA, N.; KOH, C.S.; INOUE, A. \& YANAGISAWA, N. - Demyelinating neuropathy associated with hepatitis B virus infection. Detection of immune complexes composed of hepatitis B virus surface antigen. J. neurol. Sci., 77: 203-216, 1987.

Received: 24 January 2001

Accepted: 16 April 2002 